\title{
The Influence of Heating Degree Days on Fuelwood Consumption in Households in Selected Countries of Central and Southeastern Europe
}

\section{Utjecaj broja stupanj-dana grijanja na potrošnju ogrjevnog drva u kućanstvima u nekim zemljama srednje i jugoistočne Europe}

\author{
Original scientific paper - Izvorni znanstveni rad \\ Received-prispjelo: 21. 3. 2021. \\ Accepted-prihvaćeno: 26. 5. 2021. \\ UDK: $630 * 831.1$ \\ https://doi.org/10.5552/drvind.2021.2111
}

(C) 2021 by the author(s) Licensee Faculty of Forestry and Wood Technology, University of Zagreb. This article is an open access article distributed under the terms and conditions of the Creative Commons Attribution (CC BY) license.

\begin{abstract}
Serbia is one of the few European countries that does not keep official statistics and does not have data on heating degree days. A heating degree day (HDD) represents a measure to quantify the energy needs for heating a building. In order to create a database, six meteorological stations in Serbia had been selected, for which the heating degree days were calculated for every year in the period 2010-2018. The months with the highest values of heating degree days were also determined for each year of the analyzed period. In addition to the annual level, heating degree days in the heating seasons over the analyzed period were calculated for the six selected stations, as well as the length and the average air temperature of each heating season. In Serbia, heating season officially lasts from October 15 to April 15. To determine the influence of the calculated annual heating degree days on fuelwood consumption in households in Serbia, over the period 2010-2018, multiple econometric models were formulated. The influence of the annual values of heating degree days on fuelwood consumption for household space heating in Slovenia and Croatia was analyzed, as well. The analysis of energy consumption in the households of the selected countries showed that wood fuels are mostly used for heating, primarily fuelwood. This is the reason why this type of fuel was selected for the research.
\end{abstract}

Keywords: heating degree days; heating season; fuelwood; households; space heating

SAŽETAK • Srbija je jedna od malobrojnih europskih zemalja koja ne vodi službenu statistiku i nema podatke o broju stupanj-dana grijanja. Broj stupanj-dana grijanja mjera je koja se primjenjuje za određivanje energije potrebne za grijanje objekta. Kako bi se formirala baza podataka, odabrano je šest meteoroloških postaja u Srbiji za koje je izračunan broj stupanj-dana grijanja za svaku godinu u razdoblju 2010. - 2018. Osim toga, određeni su mjeseci s najvećim brojem stupanj-dana grijanja za svaku godinu analiziranog razdoblja. Osim na godišnjoj razini, izračunan je broj stupanj-dana grijanja u sezonama grijanja tijekom analiziranog razdoblja za šest odabranih

\footnotetext{
${ }^{1}$ Author is higher education associate at University of Belgrade, Faculty of Forestry, Department of Wood Science and Technology, Belgrade, Republic of Serbia.
} 
postaja, kao i trajanje i srednja temperatura svake sezone grijanja. Sezona grijanja u Srbiji službeno traje od 15. listopada do 15 travnja. Izrađeni su višestruki ekonometrijski modeli kako bi se u kućanstvima u Srbiji u razdoblju 2010. - 2018. utvrdio utjecaj izračunanih godišnjih vrijednosti broja stupanj-dana grijanja na potrošnju ogrjevnog drva. Također je analiziran utjecaj godišnjih vrijednosti broja stupanj-dana grijanja na potrošnju ogrjevnog drva u Sloveniji i Hrvatskoj. Analiza potrošnje energije u kućanstvima u promatranim zemljama pokazala je da se za grijanje najviše iskorištava drvna biomasa, osobito ogrjevno drvo. To je i bio razlog zašto je ta vrsta goriva odabrana za istraživanje.

Ključne riječi: broj stupanj-dana grijanja; sezona grijanja; ogrjevno drvo; kućanstva; grijanje

\section{INTRODUCTION 1. UVOD}

Heating degree days can be explained as a way of climate influence on energy consumption for household space heating. Calculation of heating degree days is based on the height of the daily average air outdoor temperature values and the length of the heating season. Both of these variables depend on the type of climate that is characteristic of a particular area. Heating degree days have been analyzed in a large number of countries around the world (Belova et al., 2018; Shen et al., 2016; Spinoni et al., 2015; Sivak, 2009; Matzarakis et al., 2004). In Croatia, this type of research has been conducted for different areas in the country, as well as different time periods (Cvitan et al., 2012; Slijepčević et al., 2019).

There are three types of climate in Serbia, namely continental, temperate continental and mountain. Continental climate is characteristic of the Pannonian Plain and its peripheral area, up to an altitude of $800 \mathrm{~m}$. This type of climate is characterized by warm summers and severe winters, and warmer autumns than springs (source: Republic Hydrometeorological Service of Serbia, 2020/a). The border between the continental and temperate continental climate traverses the valley of the river Zapadna Morava, then enters the valley of the river Južna Morava, goes over the Leskovac valley and the valley of the river Nišava (Geotesla, 2021). Temperate continental climate prevails in the area south of this border up to an altitude of $1400 \mathrm{~m}$. This type of climate is characterized by moderately warm and dry summers, cold winters and warmer autumns than springs. Mountain climate that prevails at an altitude over $1400 \mathrm{~m}$ is characterized by long, severe and cold winters with plenty of snowfall and short and cool summers (Geotesla, 2021). In Croatia, there are also three main climate areas, namely: continental, mountain and maritime. Continental Croatia has a temperate continental climate, while at higher altitudes in the mountainous districts of Gorski kotar, Lika and the Dinaric Alps, mountain climate prevails. Maritime climate is characteristic of the coastal parts of the country, and is characterized by mild winter and warm summers, without extreme temperature differences between the seasons (Croatian Meteorological and Hydrological Service, 2021). Slovenia also has a temperate continental climate in most parts of the country, except in the coastal areas by the sea and in the mountains, where the maritime and mountain climate prevail (Slovenian Environmental Agency, 2021).
In addition to climate, there is a similarity between the countries in the final energy consumption in households. In 2018, households were the largest endusers of final energy in Serbia and Croatia, and the third largest in Slovenia. In households in Serbia 38.5 $\%$ of final energy was consumed, $34.4 \%$ in Croatia, and $21.6 \%$ in Slovenia (Eurostat, 2020; Food and Agriculture Organization - FAO and United Nations Development Program - UNDP projects, 2011, author's calculation). Space heating is the major use of energy in households. In 2018, households in Croatia consumed $68.3 \%$ of energy for this purpose, in Slovenia $61.2 \%$, while there was no data for Serbia.

The main goal of this research was to define the dependency between heating degree days in Belgrade, Novi Sad, Niš, Vranje, Loznica and Zlatibor and fuelwood consumption in households in Serbia. In accordance with the aim, the subject of the research was heating degree days in the six selected meteorological stations.

\section{MATERIALS AND METHODS} 2. MATERIJALI I METODE

Specialized terminology to calculate heating degree days in the six selected meteorological stations in Serbia was used, the main determinants of which are presented below. According to Živković et al. (1998), the heating day is the day when the average daily outdoor air temperature is lower than $12.0{ }^{\circ} \mathrm{C}$, and the heating limit temperature $\left(t_{\mathrm{gg}}\right)$ is the temperature that defines the beginning and end of the heating period. The heating limit temperature is $12.0^{\circ} \mathrm{C}$ in Serbia. The heating period represents the number of days, from the beginning to the end of heating, and is also called the heating season (Directive on Energy Efficiency of Buildings, 2011). Calculation of heating degree days was performed based on air temperature of $20.0^{\circ} \mathrm{C}$ in the heated room (Directive on Energy Efficiency of Buildings, 2011).

\subsection{Calculation of heating degree days}

2.1. Izračun broja stupanj-dana grijanja

The heating season in Serbia officially lasts from October $15^{\text {th }}$ of the observed year to April $15^{\text {th }}$ of the following year. However, the heating season can start in the period October $1^{\text {st }}-14^{\text {th }}$ of the observed year, if the average daily outdoor air temperature is below 12.0 ${ }^{\circ} \mathrm{C}$ in three consecutive days. Also, the heating season will be extended, if the average daily outdoor air temperature is below $12.0^{\circ} \mathrm{C}$ in three consecutive days in 
the period from April $16^{\text {th }}$ to May $3^{\text {rd }}$. These rules were followed when calculating heating degree days in Belgrade, Novi Sad, Nis, Vranje and Loznica. In the mountainous areas, on the mountain Zlatibor to be precise, the length of the heating season was determined differently. In accordance with the heating limit temperature, the calculation of the heating degree days included the months of May and September. The heating season in September began when the daily average outdoor air temperature was lower than $12.0{ }^{\circ} \mathrm{C}$ in three consecutive days. The end of the heating season was announced in May when the daily average air temperature was equal or higher than $12.0^{\circ} \mathrm{C}$ in three consecutive days. If, after three consecutive days with the temperature above $12^{\circ} \mathrm{C}$, the daily average air temperature falls below $12.0^{\circ} \mathrm{C}$ again, the heating will be switched on, only if the low temperatures last for three or more days. During the course of the heating seasons, days when the average daily air outdoor temperature was equal to or greater than $12.0{ }^{\circ} \mathrm{C}$ were not included in heating degree-days.

According to Živković et al. (1998), the calculation of annual (January to April, October to December) heating degree days over the period 2010-2018 was conducted according to the following formula:

$$
H D D=Z \cdot\left(t_{\mathrm{u}}-t_{\mathrm{gg}}\right)+\sum\left(t_{\mathrm{gg}}-t_{\mathrm{sn}}\right)
$$

Where: $Z$ - number of days in the month when the difference between the limit heating temperature and the average daily outdoor air temperature was lower than $12.0^{\circ} \mathrm{C} ; t_{\mathrm{u}}$ - air temperature in heated spaces in residential buildings in the heating season $\left(20.0^{\circ} \mathrm{C}\right) ; t_{\mathrm{gg}}$ - heating limit temperature $\left(12.0^{\circ} \mathrm{C}\right) ; t_{\mathrm{sn}}$ - average daily outside temperature over the heating period.

In Slovenia and Croatia, the same values of the heating temperature limit and the air temperature in heated space in residential buildings as those recorded in Serbia were used to calculate heating degree days (Slovenian Environmental Agency, 2021; Slijepčević et al., 2019). Data for heating degree days for the countries in the period 2010-2018 were taken from the Eurostat database.

\subsection{Characteristics of the selected meteorological} stations in Serbia

2.2. Obilježja odabranih meteoroloških postaja u Srbiji

The selection of meteorological stations for the calculation of heating degree days was carried out by a combination of the following criteria:

- the number of inhabitants of a city where the meteorological station is located;

- climate (in addition to the influence of basic types of climate, special attention is paid to climate subtypes; their influence is characteristic of certain, smaller areas in the country where specific geographical features change the climate making it different from the climate of the environment);

- the district where the meteorological station is located.

According to the first criterion, meteorological stations located in the three largest cities in Serbia, namely Belgrade, Novi Sad and Niš were selected. In Serbia, $23.09 \%$ of the total population lives in Belgrade, $4.75 \%$ in Novi Sad and $3.62 \%$ in Niš (Statistical Office of the Republic of Serbia, 2021). It is assumed that the largest cities have the greatest influence on final energy consumption in households, especially their suburbs where fuelwood is used the most. Based on the second criterion, a meteorological station in Vranje, a city in southern Serbia, was chosen. The modified Mediterranean climate prevails in Vranje, moderately continental in Belgrade and Niš, and in Novi Sad it varies from moderately continental to continental. To consider the influence of the mountain climate on fuelwood consumption in households, a meteorological station on the mountain Zlatibor was chosen. The research conducted during the implementation of the FAO and UNDP projects has shown that households in Western Serbia are large consumers of fuelwood. This was the reason to select the meteorological station located in the city of Loznica that has a temperate continental climate. The six selected meteorological stations are located in different districts in Serbia. There are 29 districts in Serbia, with Belgrade being an independent territorial unit, Novi Sad belonging to the South Bačka District, Niš to the Nišava District, Vranje to the Pčinja District, Zlatibor to the Zlatibor District, and Loznica to the Mačva District.

\subsection{Data sources}

\subsection{Izvori podataka}

The calculation of heating degree days for the selected meteorological stations in Serbia was done for the period 2010-2018. There are no data on fuelwood consumption in households in Serbia for the period before 2010. The analysis of fuelwood consumption in households in Serbia was conducted on the basis of data taken from the European Eurostat database, the census of population, households and dwellings in the Republic of Serbia, as well as certain FAO and UNDP projects. The research conducted for the purposes of these projects has shown that the real data values of fuelwood consumption in households in Serbia are much higher than the official data recorded in the Eurostat database. In 2018, according to projects results, energy consumption from fuelwood in households in Serbia was $60.8 \%$ higher than energy consumption from wood fuel in households, as recorded in the Eurostat database. The implementation of the projects provided data on the total consumption of fuelwood in households, whereby it was not divided according to the purpose of consumption. Therefore, the influence of heating degree days on energy consumption from fuelwood for all purposes in households in Serbia was examined. Also, the influence of heating degree days on fuelwood consumption for household space heating in Slovenia and Croatia was examined.

\subsection{Econometric modeling}

2.4. Ekonometrijsko modeliranje

Regression analysis was conducted to determine the functional dependency of heating degree days on 
fuelwood consumption in households in Serbia in the period 2010-2018. Multiple econometric models were formulated with four (out of a total of six) independent variables. Durbin-Watson test (DW) of autocorrelation was a limiting parameter for the number of variables in the models, given that the data series had been used for nine years. K-combinations of $n$ elements, without repetition determined the total number of the analyzed models. To this purpose, the following formula was applied (Rakočević, 1983):

$$
C_{\mathrm{n}}^{\mathrm{k}}=\left(\frac{n}{k}\right)=\frac{n !}{k !(n-k) !}
$$

Where: $k$ - number of meteorological stations in the multiple econometric model (4); $n$ - total number of meteorological stations (6).

In accordance with the applied formula, $15 \mathrm{mul}$ tiple econometric models were formulated. The choice of the multiple econometric model to determine the analyzed dependency was made according to the highest value of the adjusted correlation coefficient. Single econometric models were formulated to examine the dependency between heating degree days in Croatia and fuelwood consumption for household space heating in the country, as well as in Slovenia. The choice of the single econometric model was made according to the highest coefficient of determination. The statistical significance of the calculated parameter in the model equation was assessed using Student's t-test. Statistical significance of the correlation coefficient was assessed by F-test. In order to determine the autocorrelation in econometric models, Durbin Watson test was used. Econometric models were developed by using software package STATISTICA 7.0.

\section{RESULTS AND DISCUSSION \\ 3. REZULTATI I RASPRAVA}

This chapter contains the following segments: Heating degree days in selected meteorological stations in Serbia; Heating degree days over heating seasons in Serbia in the period 2010-2018; Energy consumption in household in Serbia; Energy consumption for household space heating in Croatia and Slovenia; The influence of heating degree days on fuelwood consumption in households in Serbia; and The influence of heating degree days on fuelwood consumption for household space heating in Slovenia and Croatia.

\subsection{Heating degree days in selected} meteorological stations in Serbia

3.1. Broj stupanj-dana grijanja u odabranim meteorološkim postajama u Srbiji

Over the analyzed period in Serbia, Zlatibor had the highest annual value of heating degree days, Belgrade the lowest, while Novi Sad, Loznica, Niš and Vranje had similar values slightly higher than Belgrade (Figure 1).

The highest values of heating degree days for all the analyzed stations were recorded in 2011 (Table 1). Except for Zlatibor, the lowest values of heating degree days for all the analyzed stations were recorded in 2014. The lowest value of heating degree days was recorded in 2018 on Zlatibor. It was a result of extremely warm April and May, which had 9 heating days. In contrast, in the same period in 2014 there was 43 heating days.

Comparing the last and the first year of the analyzed period, all the analyzed stations had the higher heating degree days in 2018 than in 2010. The largest difference between heating degree days of 529.2 was determined for Zlatibor, followed by Novi Sad - 283, Loznica - 291.4, Belgrade - 143.1, Vranje - 69.1 and the lowest for Niš - 31.8. The highest values of heating degree days were recorded in January, February or December. In January, they were recorded in 2010, 2011, 2013, 2015 and 2017, in February 2012, and in December 2014, 2016 and 2018. The highest values of heating

Table 1 The highest and the lowest value of heating degree days in the period 2010-2018

Tablica 1. Najviše i najniže vrijednosti broja stupanj-dana grijanja u razdoblju 2010. - 2018 .

\begin{tabular}{|l|c|c|c|}
\hline \multirow{2}{*}{$\begin{array}{l}\text { Meteorological stations } \\
\text { Meteorološke postaje }\end{array}$} & \multicolumn{3}{|c|}{$\begin{array}{c}\text { Heating degree days } \\
\text { Broj stupanj-dana grijanja }\end{array}$} \\
\cline { 2 - 4 } & 2011 & 2014 & 2018 \\
\hline Zlatibor & $3,841.1$ & - & $3,260.4$ \\
\hline Vranje & $3,092.6$ & $2,277.7$ & - \\
\hline Novi Sad & $2,905.5$ & $2,158.7$ & - \\
\hline Niš & $2,814.3$ & $2,169.0$ & - \\
\hline Loznica & $2,784.3$ & $2,108.8$ & - \\
\hline Belgrade & $2,579.8$ & $1,969.6$ & - \\
\hline
\end{tabular}

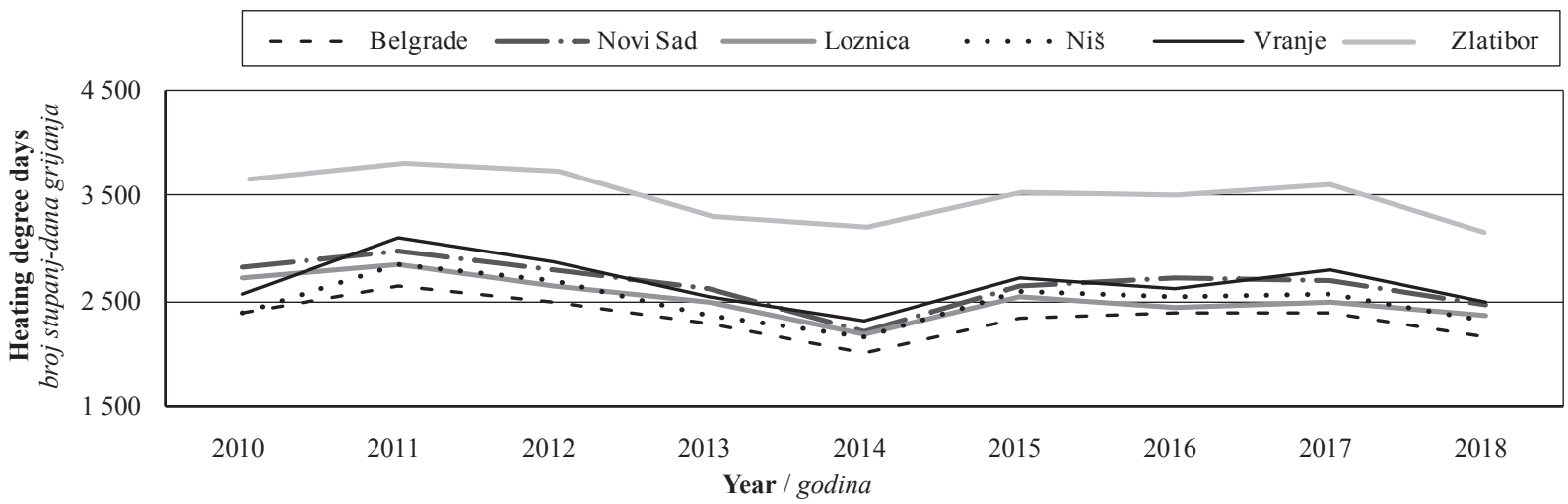

Figure 1 Heating degree days in selected meteorological stations in Serbia in the period 2010-2018

Slika 1. Broj stupanj-dana grijanja u odabranim meteorološkim postajama u Srbiji u razdoblju 2010. - 2018. 
degree days were recorded on Zlatibor in January 2017, in February 2012, and December 2016.

\subsubsection{Heating degree days over heating seasons in the period 2010-2018 \\ 3.1.1. Broj stupanj-dana grijanja tijekom sezone} grijanja u razdoblju 2010. - 2018.

The lowest values of heating degree days over heating seasons, over the period 2010-2018, were recorded in Belgrade, and the highest on Zlatibor, while slightly higher values than Belgrade were recorded in Niš, Loznica, Novi Sad and Vranje. The highest values of heating degree days, in all meteorological stations, were recorded in 2011/2012 heating season, and the lowest in 2013/2014. The highest value of heating degree days of 3993.8 was recorded on Zlatibor, followed by Vranje 3191.8, Novi Sad 2970.8, Niš 2905.3, Loznica 2841.9, and Belgrade 2640. In 2013/2014 heating season, the lowest value of heating degree days of 1939.5 was recorded in Belgrade, followed by Niš 2119.4, Loznica 2185.7, Novi Sad 2199.5, Vranje 2293.7 and Zlatibor 3301.6.

The comparative analyses of the heating season length in Belgrade, Novi Sad, Niš, Loznica, and Vranje over the period 2010-2018 showed that it was in the interval between 140 days and 181 days. In Belgrade, Niš and Novi Sad, the longest heating season was 2016/2017, and in Loznica and Vranje 2011/2012. Except in Loznica, where the season 2017/2018 was the shortest heating season, in all the other stations it was the season 2013/2014. Also, 2017/2018 heating season was longer than 2010/2011 only in Belgrade, while in the other stations it was shorter. The shortest heating season over the analyzed period, lasting for 140 days, was recorded in Belgrade. Niš and Loznica have always had longer heating season than Belgrade, as well as Novi Sad and Vranje. The longest heating season in Niš lasted for 169 days, in Loznica 170 days, and in Novi Sad 176 days. The longest heating season of 181 days was recorded in Vranje in 2011/2012. On Zlatibor, the heating seasons have different characteristics compared to the other five analyzed places. The longest heating season of 225 days was 2010/2011, and the shortest of 192 days 2017/2018. Accordingly, over the analyzed period, the heating season length on Zlatibor started to decrease, the largest difference between the heating seasons' length being 33 days. The lowest val- ues of average air temperature during the heating seasons in Novi Sad, Niš, Loznica, Vranje and Zlatibor were recorded in 2011/2012, while in Belgrade it was the case in 2010/2011. The lowest average temperature of $1.07{ }^{\circ} \mathrm{C}$ was recorded on Zlatibor, in Vranje slightly higher, $2.36{ }^{\circ} \mathrm{C}$, followed by Niš $2.60{ }^{\circ} \mathrm{C}$, Novi Sad $2.73{ }^{\circ} \mathrm{C}$, Loznica $3.29^{\circ} \mathrm{C}$ and Belgrade $3.44{ }^{\circ} \mathrm{C}$. The warmest heating season in Belgrade, Niš, Loznica and Zlatibor was in 2013/2014 and in Novi Sad and Loznica in 2015/2016. Belgrade recorded the highest average air temperature of a heating season of $6.15^{\circ} \mathrm{C}$, followed by Loznica $5.75^{\circ} \mathrm{C}$, Niš $5.58^{\circ} \mathrm{C}$, Novi Sad 5.47 ${ }^{\circ} \mathrm{C}$, Vranje $5.39^{\circ} \mathrm{C}$, and Zlatibor $4.50{ }^{\circ} \mathrm{C}$ (Figure 2).

\subsubsection{Energy consumption in households in Serbia \\ 3.1.2. Potrošnja energije u kućanstvima u Srbiji}

In 2018, $101.996 \mathrm{TJ}$ of final energy was consumed in households in Serbia (Sources: Eurostat 2020, FAO and UNDP projects, author's calculations). With the exception of 2010, when enormous electricity consumption was recorded, in the remaining years of the analyzed period, the consumption of final energy in households was without major oscillations.

Wood fuels are mostly used for household space heating, followed by fossil fuels and district heating, and, finally, electricity. In the group of wood fuels, fuelwood is mostly used, while the consumption of wood pellets and briquettes is significantly lower. In 2018, energy consumption from fuelwood was higher than in 2010. Unlike fuelwood, energy consumption from fossil fuel for space heating was lower in 2018 compared to 2010 . Coal was mostly used, followed by natural gas, and petroleum products as the least used

\subsubsection{The influence of heating degree days on fuelwood consumption in households in Serbia}

3.1.3. Utjecaj broja stupanj-dana grijanja na potrošnju ogrjevnog drva u kućanstvima u Srbiji

By formulating multiinple econometric models, it was determined that the changes in heating degree days in Novi Sad, Loznica, Zlatibor and Vranje have the greatest influence on fuelwood consumption in households in Serbia. The influence of heating degree days on fuelwood consumption in households in Serbia is best described by a multiple econometric model (the highest value of adjusted correlation coefficient), with Eq. 3:

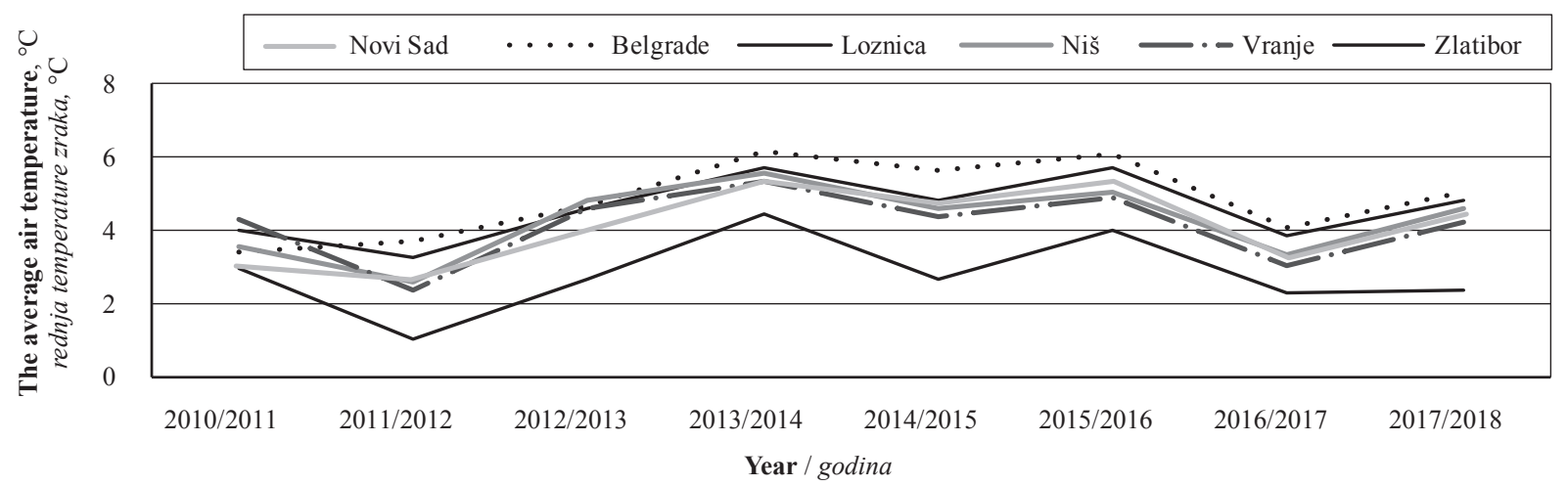

Figure 2 The average air temperature of heating seasons in selected meteorological stations in the period 2010-2018 Slika 2. Srednja temperatura zraka tijekom sezone grijanja u odabranim meteorološkim postajama u razdoblju 2010. - 2018. 
Table 2 The values of the basic parameters of the model

Tablica 2. Vrijednosti osnovnih parametara modela

\begin{tabular}{|c|c|c|c|c|c|c|}
\hline \multicolumn{2}{|c|}{ Parameter } & St. error & $t$-test & $\mid t$-test $\mid$ & $F_{(4,4)}$ & $F_{\text {test (0.05) }}$ : \\
\hline$a$ & $\ln =12.45253$ & 0.551940 & 22.56139 & $>t_{0.05}$ & \multirow{5}{*}{2.5114} & \multirow{5}{*}{ 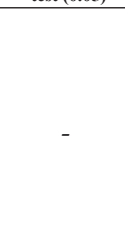 } \\
\hline$b$ & 0.24648 & 0.148699 & 1.65755 & $<t_{0.05}$ & & \\
\hline$c$ & -0.20489 & 0.13226 & -1.54916 & $<t_{0.05}$ & & \\
\hline$d$ & -0.32017 & 0.112997 & -2.83345 & $>t_{0.05}$ & & \\
\hline$e$ & 0.10211 & 0.083928 & 1.21660 & $<t_{0.05}$ & & \\
\hline
\end{tabular}

$$
Y=255896.9 \cdot x_{1}^{0.24648} \cdot x_{2}^{-0.20489} \cdot \mathrm{x}_{3}^{-0.32017} \cdot x_{4}^{0.10211}
$$

Where: $x_{1}$ - heating degree days in Novi Sad; $x_{2}$ - heating degree days in Loznica; $x_{3}$ - heating degree days in Zlatibor; $x_{4}$ - heating degree days in Vranje.

The calculated value of the correlation coefficient of 0.84 shows a very high correlation between the analyzed variables. In addition, the value of the coefficient of determination shows that $71.5 \%$ of the variations in the fuelwood consumption in households in Serbia may be explained by the changes in heating degree days in Novi Sad, Loznica, Zlatibor and Vranje. The value of DW statistics is 1.72 , so it cannot be stated with certainty if the model has an autocorrelation. Since the parameters b, c and e are not significant, larger deviations from the stated value can be expected. The basic parameters of this model are given in Table 2.

The calculated values of individual parameters in the model equation mean that if the variables representing heating degree days in:

- Novi Sad $\left(x_{1}\right)$ and Vranje $\left(x_{4}\right)$ increase by $1.0 \%$, the fuelwood consumption in households in Serbia will increase by $0.25 \%$ and $0.10 \%$, and if the variables in

- Loznica $\left(x_{2}\right)$ and Zlatibor $\left(x_{3}\right)$ increase by $1.0 \%$, the fuelwood consumption in households in Serbia will decrease by $0.20 \%$ and $0.32 \%$.

The research was based on the assumption that, with the increase in heating degree days in selected meteorological stations, fuelwood consumption in households in Serbia will increase. However, different results were obtained, which showed that the increase in heating degree days in Loznica and Zlatibor causes a decrease in fuelwood consumption in households in Serbia. These results may be explained by the fact that households purchase certain quantities of fuelwood before the start of the heating season. If the heating season is extended and the prepared quantity of wood is consumed, households have two options, either to procure new quantities of fuelwood or to use alternative fuel. When the heating season extends, the demand for energy sources on the local market grows and their price rises accordingly. This rule does not apply to electricity and therefore one part of households uses this energy source as a supplement. Also, some households that use fuelwood for space heating combine it with coal. The price competitiveness of energy source will significantly influence the decision whether to procure additional quantities of wood or coal. Also, it must be taken into account whether fuelwood can be purchased as split or unsplit.

\subsection{Energy consumption for household space} heating in Slovenia

3.2. Potrošnja energije za grijanje u kućanstvima u Sloveniji

In 2018, energy consumption for household space heating in Slovenia of 27,313.4 TJ was $28.8 \%$ lower than in 2010 (Statistical Office of the Republic of Slovenia, 2020).

Wood fuels are mostly used for space heating, followed by fossil fuels, significantly less district heating and electricity, and geothermal and solar energy as the least used. Fuelwood is mostly used for household space heating, followed by wood pellets, while consumption of wood chips, briquettes and the consumption residues is much lower. In 2018, the consumption of fuelwood was lower than in 2010, unlike the consumption of wood pellets and the consumption of wood chips, briquettes and residues. Also in 2018, the consumption of fossil fuels was lower than in 2010. Extra light oil and LPG are mostly used for space heating, followed by natural gas, while coal consumption is symbolic.

\subsubsection{The influence of heating degree days on fuelwood consumption for household space heating in Slovenia}

3.2.1. Utjecaj broja-stupanj dana grijanja na potrošnju ogrjevnog drva za grijanje kućanstava u Sloveniji

Over the period 2010-2018, heating degree days in Slovenia dropped from a record 3136.59 to 2579.61 . The lowest value of 2345.72 was recorded in 2014 (Eurostat, 2021). In Slovenia, heating degree days are specially defined for 13 areas. The highest value of 3457.3 was recorded in 2010 in the area of Gorenjska and the lowest of 1840.74 in the area of Obalno-kraska in 2014.

The influence of the heating degree days on fuelwood consumption for household space heating in Slovenia $A$ is best described by a simple econometric model (the highest value of coefficient of determination), with Eq. 4:

$$
Y=5.64 \cdot x^{1.02}
$$

Positive parameter $\mathrm{b}$ and its statistical significance show that, with the increase in the heating degree days in Slovenia of $1.0 \%$, an increase in fuelwood consumption for household space heating of $1.02 \%$ can be expected. The basic parameters of this model are given in Table 3.

The value of the correlation coefficient of 0.84 is quite high and it is statistically significant, so it means 
Table 3 The basic parameters of the econometric mode

Tablica 3. Vrijednosti osnovnih parametara ekonometrijskog modela

\begin{tabular}{|c|c|c|c|c|c|c|}
\hline \multicolumn{2}{|c|}{ Parameter } & $\boldsymbol{S}$ & $\boldsymbol{t}$-test & $\mid \boldsymbol{t}$-test & $\boldsymbol{F}_{(1,7)}$ & $\boldsymbol{F}_{\text {test (0.05) }}:$ \\
\cline { 1 - 5 }$a$ & $\ln =1.730259$ & 1,979258 & 0,874195 & $<t_{0.05}$ & \multirow{2}{*}{16,701} & + \\
\cline { 1 - 5 } & 1.020935 & 0,249821 & 4,086658 & $>t_{0.05}$ & & + \\
\hline
\end{tabular}

Table 4 The values of other model parameters

Tablica 4. Vrijednosti ostalih parametara modela

\begin{tabular}{|c|c|c|c|c|c|c|}
\hline \multicolumn{2}{|c|}{ Parameter } & $\boldsymbol{S}$ & $\boldsymbol{t}$-test & $\mid \boldsymbol{t}$-test $\mid$ & $\boldsymbol{F}_{(1,7)}$ & $\boldsymbol{F}_{\text {test (0.05) }}:$ \\
\hline$a$ & $\ln =6.172837$ & 0.879585 & 7.017897 & $>t_{0.05}$ & \multirow{2}{*}{26.646} & + \\
\hline$b$ & 0.587916 & 0.113894 & 5.161970 & $>t_{0.05}$ & & + \\
\hline
\end{tabular}

that there is a very high correlation between the consumption of fuelwood for household space heating in Slovenia and heating degree days. The value of coefficient of determination shows that $70.5 \%$ of the variation in fuelwood consumption for household space heating in Slovenia can be explained by the change in heating degree days. The value of DW statistics is 0.99 , which means that it cannot be claimed with certainty whether the model has an autocorrelation.

\subsection{Energy consumption for household space heating in Croatia}

3.3. Potrošnja energije za grijanje kućanstava u Hrvatskoj

In 2018, energy consumption for household space heating in Croatia was at the level of $65.745 \mathrm{TJ}$, or $18.1 \%$ lower than in 2010 (Eurostat, 2021). This means that in the period 2010-2018, consumption decreased at an average annual rate of $2.5 \%$.

Wood fuels are mostly used for household space heating, namely fuelwood, while the use of wood pellets and briquettes is significantly lower. Fossil fuels are the second most important energy source for household space heating, but their consumption decreased significantly over the period 2010-2018. Energy consumption from coal decreased the most, by $62.5 \%$, followed by petroleum products by $52.2 \%$ and natural gas by $21.8 \%$ (Eurostat, 2021).

\subsubsection{The influence of heating degree days on fuelwood consumption for household space heating in Croatia}

3.3.1. Utjecaj broja stupanj-dana grijanja na potrošnju ogrjevnog drva za grijanje kućanstava u Hrvatskoj

In Croatia, over the period 2010-2018, heating degree days decreased from a maximum of 2,521.22, to $2,076.47$. The minimum value of $1,885.28$ was recorded in 2014 (Eurostat, 2021). Official data for heating degree days are defined for 23 areas. The highest value of heating degree days was recorded in 2010 in the Lika-Senj area $(3,040)$ and the lowest in 2014 in the amount of 1293 in the Split-Dalmatia area. Zagreb, the capital of Croatia, had a record value of heating degree days of 2715 in 2010, and 2216 in 2018. The lowest value of 1,957 was recorded in 2014 (Eurostat, 2021).

The influence of the heating degree days on fuelwood consumption for household space heating in
Croatia is best described by a simple econometric model (the highest value of coefficient of determination), with Eq. 5:

$$
Y=1116.44 \cdot x^{0.59}
$$

The positive parameter $b$ and its statistical significance show that, with an increase in heating degree days in Croatia of $1.0 \%$, an increase of fuelwood consumption for household space heating of $0.59 \%$ can be expected. The value of correlation coefficient of 0.89 shows that there is an extremely high correlation between the analyzed variables, while the value of coefficient of determination shows that $79 \%$ of the variation in fuelwood consumption for household space heating can be explained by the change in heating degree days. Other model parameters have the values from Table 4.

\section{CONCLUSIONS}

\section{ZAKLJUČAK}

By formulating multiple econometric models, it was determined that the changes in heating degree days in Novi Sad, Loznica, Zlatibor and Vranje have the greatest influence on fuelwood consumption in households in Serbia. The model equation defines that with the increase in heating degree days in Novi Sad and Vranje, an increase in consumption of firewood in households of $0.25 \%$ and $0.10 \%$ can be expected. Similarly, with the increase in heating degree days in Loznica and Zlatibor, a decrease in fuelwood consumption of $0.20 \%$ and $0.32 \%$ can be expected. By simple econometric models for Slovenia and Croatia, it has been proved that, if the heating degree days in these countries increase by $1.0 \%$, an increase in fuelwood consumption for household space heating of 1.02 $\%$ and $0.59 \%$ can be expected in Slovenia and Croatia, respectively.

In the coming period, it is necessary to expand the research and create database for heating degree days in all districts in Serbia. Creating a database is the first step for all subsequent research in this field. The econometric models have shown the initial dependency of firewood consumption in households in Serbia, Croatia and Slovenia on the heating degree days. Certainly, other factors affect the firewood consumption in 
households and they must be the subject of further research.

\section{REFERENCES}

\section{LITERATURA}

1. Belova, I. N.; Ginzburg, A. S.; Krivenok, Lj., 2018: Heating seasons length and degree days trends in Russian cities during last half century research study. Energy Procedia, 149: 373-379.

https://doi.org/10.1016/j.egypro.2018.08.201.

2. Cvitan, L.; Jurković, S. R., 2012: Promjene potreba za grijanjem i hlađenjem u Hrvatskoj u razdoblju 1901 2008. Croatian Meteorological Journal, 46: 27-33.

3. Glavonjić B.; Petrović, S., 2009: Ekonomika drvne industrije - praktikum. Univerzitet u Beogradu, Šumarski fakultet, Republika Srbija, ISBN: 978-86-7299-162-8.

4. Matzarakis, A.; Balafoutis, Ch., 2004: Heating degree days over Greece as an index of energy consumption. International Journal of Climatology, 24: 1817-1828. https://doi.org/10.1002/joc.1107.

5. Rakočević, K., 1983. Matematika - I knjiga. Beograd: Savremena administracija.

6. Shen, X.; Liu, B., 2016: Changes in the timing, length and heating degree days of the heating season in central heating zone of China. Scientific Reports, 6: 33384. https://doi.org/10.1038/srep33384.

7. Sivak, M., 2009: Potential energy demand for cooling in the 50 largest metropolitan areas of the world: Implications for developing countries. Energy Policy, 37 (4): 1382-1384. https://doi.org/10.1016/j.enpol.2008.11.031.

8. Slijepčević, S.; Mikulić, D.; Horvat, K., 2019: Evaluation of the cost-effectiveness of the installation of heatcost allocators in multifamily buildings in Croatia. Energies 12 (3): 507. https://doi.org/10.3390/en12030507.

9. Spinoni, J.; Barbosa, P.; Vogt, V. J., 2015: European degree-days climatologies and trends for Europe for the period 1951-2011. International Journal of Climatology, 35 (1): 25-36. https://doi.org/10.1002/joc.3959.

10. Živković, B.; Novoselac, A., 1998: Criteria for Degree Days Number Calculation. KGH - Klimatizacija, grejanje, hlađenje [S.1.], 27 (4): 45-48 (online).https://izdanja.smeits.rs/index.php/kgh/article/view/652 (Accessed Jan. 15, 2021).

11. ${ }^{* * *}$ 2021: Croatian Meteorological and Hydrological Service (online). https://meteo.hr/klima.php?section=klima_ hrvatska\&param=k1 (Accessed Jan. 27, 2021).
12. ${ }^{* * *}$ 2020: EUROSTAT - Statistics Database (online). https://ec.europa.eu/eurostat/data/database (Accessed Nov. $20,2020)$

13. ${ }^{* * *}$ 2010-2011: FAO - Food and Agriculture Organization: Wood energy for sustainable rural development $\mathrm{TCP} /$ YUG/3201.

14. ${ }^{* * *}$ 2021: Geotesla (online). https://geotesla.wordpress. com/2019/11/10/klimatske-karakteristike-srbije/ (Accessed Jan. 25, 2021).

15. ${ }^{* * *} 2020 \mathrm{a}$ : Republic Hydrometeorological Service of Serbia (online). http://www.hidmet.gov.rs/ciril/meteorologija/klimatologija_temp_rezim.php (Accessed Dec. 25, 2020).

16. ${ }^{* * *} 2020 \mathrm{~b}$ : Republic Hydrometeorological Service of Serbia: Meteorological Annual - Climatological Data (online). http://www.hidmet.gov.rs/latin/meteorologija/klimatologija godisnjaci.php (Accessed Nov. 18, 2020).

17. ${ }^{* * *}$ 2021: Slovenian Environmental Agency (online). http://meteo.arso.gov.si/met/en/climate/ (Accessed Jan. 25, 2021).

18. ${ }^{* * *}$ 2011: Službeni glasnik Republike Srbije: Pravilnik o energetskoj efikasnosti zgrada, broj 61 (online). https:// www.mgsi.gov.rs/sites/default/files/PRAVILNIK\%20 O\%20ENERGETSKOJ\%20EFIKASNOSTI\%20ZGRADA.pdf (Accessed Jan. 15, 2021).

19. ${ }^{* * *} 2020$ : Statistical Office of the Republic of Slovenia (online). https://www.stat.si/StatWeb/en (Accessed Nov. 21, 2020).

20. ${ }^{* * *} 2021$ : Statistical Office of the Republic of Serbia (online). http://media.popis2011.stat.rs/2011/prvi_rezultati. pdf (Accessed Jan. 15, 2021).

21. ${ }^{* * *}$ 2019: UNDP - United Nation Development Programm, Project: Reducing barriers to accelerate the development of biomass markets in Serbia: 2013 - 2019.

\section{Corresponding address:}

\section{SLAVICA PETROVIĆ, PhD}

University of Belgrade, Faculty of Forestry

Department of Wood Science and Technology

Kneza Viseslava 1, 11030 Belgrade, REPUBLIC OF SERBIA

e-mail: slavica.petrovic@sfb.bg.ac.rs 